\title{
Drifting towards innovation: The co-evolution of patent networks, policy, and institutions in China's solar photovoltaics industry
}

\begin{abstract}
Since 2008, China has become the dominant force in solar cell production in the world. What about technological development and innovation? This paper contributes to a better understanding of the accumulation process of indigenous innovation capabilities in emerging economies. It empirically analyses the case of photovoltaic (PV) technologies in China between 1988 and 2014 using patent indicators with a comprehensive definition of the entire system value chain. The contribution tracks the technological catching-up trajectory of the PV innovators in China and their collaboration networks against institutional milestones of industrial policy. Theoretically, the research draws on the concepts of innovation capabilities and technological systems. Methodologically, the paper uses patent indicators and network analysis to study patent co-application activities. The analysis shows a gap between China's share in the global PV market and its modest share of transnational patents. However, it gives evidence for a gradual technological catching-up in the $1 \mathrm{G}$ cell technologies, solar panels, and electronics. An increasing population of Chinese patent applicants clustered in isolated communities has driven technological catching-up in solar photovoltaics. The role of foreign actors in the co-patenting activities is surprisingly low and decreasing.
\end{abstract}

KEYWORDS: Photovoltaics; China; Network Analysis; Transnational Patents;

JEL CLASSIFICATION: D85; O31; O34; Q42; Q55 


\section{INTRODUCTION}

This paper contributes to a better understanding of catching-up processes and economic development in emerging economies by studying the case of solar photovoltaics (PV) in China. Considering that China is a late-comer innovator in the PV industry, the paper applies patent and network analysis to shed light on the technological path underlying China's industrial development and the accumulation process of domestic innovation capabilities in the field.

There is strong evidence of the intensive research and development (R\&D) efforts taking place in China in the last decades. China's technological development can be tracked empirically from both sides: input and output. On the one hand, Chinese spending in R\&D has been growing rapidly since the beginning of the third millennium [1]. R\&D as a share of GDP increased from $1.4 \%$ in 2007 to $2.05 \%$ in 2014, reaching almost the OECD level $(2.38 \%$ in 2014$)$ and well beyond the share reached in the European Union $(1.9 \%$ in 2014). On the other hand, patent and trademark data suggest that China is gradually becoming an important player in the global landscape of innovation [2].

Science, technology and innovation studies have largely acknowledged that processes of technological change in countries are shaped by sector/technology specific institutions unfolding in particular cycles, trends and industry dynamics that cannot be explained exclusively by national forces $[3,4,5]$. From this perspective, our understanding of catching-up processes in China can very much benefit from the study of technological development in a specific field.

The development, production, and use of solar PV technology for generating electricity is growing rapidly all over the world [6]. Technology development and diffusion in terms of increasing production volumes, cells efficiencies, and installed capacities of PV power plants are taking place in developed and developing countries, where China has gradually become an important player [6, 7]. In 2003, China's share in PV global production was less than $1 \%$, however, it rapidly built up its capabilities to become the dominant force in solar cell manufacturing in the world in 2008 [8]. In 2013, China accounted for $60 \%$ of the global PV cell production [9] having more than 500 solar PV firms [8]. Together with the increasing activities in manufacturing crystalline silicon (c-Si) PV cells, there is evidence that China has gradually accumulated indigenous capabilities in advanced technologies in upstream segments of the industry $[10,11,12,13,14]$.

Against this rapid growth of China's share in the global PV market, we examine whether a similar trend can be found in technological development and innovation. Using patent indicators, the paper analyses the Chinese innovation capabilities in PV technologies over the period 1988-2014. It further identifies the main actors in the field and the technological knowledge networks they are embedded in. More specifically the paper aims at answering the following research questions:

- To which extent is China accumulating innovation capabilities in PV technologies?

- Which technological catching-up trajectory has China followed in the PV sector?

- Which has been the role of local and foreign actors in this process? 
- How have the underlying technological networks evolved over time?

The paper is structured in six sections. The next section summarises the state of the art in research studying the development of the Chinese PV industry. The conceptual framework guiding the empirical analysis of the paper is presented in section 3 . In section 4, we introduce the data sources, methods, and indicators used. The empirical analysis of China's position in the global PV technology landscape, China's technological catchingup trajectory, and the underlying technological networks are presented in section 5 . We conclude in section 6 by discussing the main results.

It is worth mentioning that the paper is highly descriptive. It uses patent and network analysis to delve into the Chinese PV innovation system with great technical detail. Patent and network indicators map the main actors driving technological catching-up along with their interactions.

\section{LITERATURE REVIEW}

The rapid development of the PV industry in China makes the Chinese case especially interesting for studying processes of technological change in catching-up economies.

Huang et al. [15] apply history event analysis to describe the Chinese success. They identify four phases of PV industrial development between 1985 and 2012. First, modest industrial activities in the manufacturing and use of PV systems in China occurred in the context of the socialist economy during 1985-1996. At this stage, PV products were not been used for civil applications [14]. With the encouragement of private entrepreneurial activities in the PV field, industrial activities scaled up. Foreign turnkey production lines as well as manufacturing equipment for solar cells were acquired by a few Chinese firms. In the period 1997-2003 this foreign technological acquisition triggered a learning process supported by continuous interaction between foreign PV producers and Chinese actors [15, p. 782]. The entrance of China in the World Trade Organization in 2001 opened the Chinese economy with strong stimulating effects for PV manufacturing. Interactions with the global PV value chain favoured the acquisition and use of foreign technologies with important learning effects for Chinese actors. Because of China's late entrance, well-working turnkey production lines were available that enabled learning effects from technology adoption [15, 13]. At the same time, policy targeted the development of PV technology from 2001 onwards, including it in national plans and in specific research programs. Foreign projects and domestic capital triggered the development of the industry as the influence of global forces continued to shape the Chinese PV industry. Between 2004-2008 the industry benefited from the increasing European demand as well as from the strong support of the Chinese government. The increasing global demand for PV originated a shortage in key raw materials for cell manufacturing (high purity polycrystalline silicon) increasing the prices considerably in 2004. Demand and price developments triggered further entrepreneurial activities. Most importantly, the global market brought up additional incentives for Chinese PV cell manufactures to improve their technologies in polycrystalline silicon-manufacturing [16, $15,13]$. At this stage, "it seems that the development of the competence in PV machinery 
design and manufacturing did not come from technology import, but from the R\&D development of the Chinese machinery manufacturers" [15, p. 783]. Although Chinese PV machinery was still lagging behind the advanced level of international machinery and the value chain was still dependent on imported technology, Chinese actors were able to develop technological competencies becoming strong competitors in the global market [13, p. 201, 15, p. 785]. The industrial and technological dynamic observed in the supply of PV cell manufacturing, (especially in c-Si cell machinery), was not accompanied by increases in the domestic demand which developed very slowly making the Chinese PV industry fully export oriented. The last period discussed in the literature (2009-2012) has been characterized by the overcapacity of the domestic supply, the strong domestic competition (obstructing research and development activities and experimentation) and the slowdown of the global demand for PV. This situation forced the Chinese government to implement several measures to promote the domestic market including a feed-in tariff (FIT) for PV generation established in 2011 [16]. Scholars view the weak domestic market for PV and the lack of market supervision as important obstacles for the further development of the Chinese PV industry [13, 15].

Researchers have studied this development to identify the main factors influencing the rapid industrialization of the PV sector in China. The role of policy has been an important research focus. Even though the industry starts developing before the explicit engagement of the Chinese government in the sector, the government has modified the legal framework, introduced market incentives and implemented industrial and research policy instruments explicitly targeting the development of the PV industry $[17,18,19,20]$.

Interestingly, research suggests that policy regimes in developed economies have largely influenced the Chinese experience as well [21, 11]. Quitzow [21] studies the interactions between the Chinese and the German technological innovation systems at the national level and the reciprocal influences via transnational linkages. Iizuka [11] stresses how the industrial and technological paths in leading economies can influence the industrialization of the PV sector in a latecomer economy. In the case of Chinese PV industry, the influence occurred on the one hand through international trade and, on the other hand, through the impact of the policy implemented in Europe (large subsidies such as FITs). Policy instruments for technology deployment in developed countries opened up market opportunities for Chinese manufacturers promoting exports and the formation of the Chinese PV industry.

In what concerns technological catching-up and innovation, a number of contributions have studied the technological path underlying the Chinese PV industrial development using different empirical approaches such as export data, field interviews, and company case studies [22, 12, 13, 14] Only [22] use patent indicators for the period 1997-2007. ${ }^{1}$ All these contributions take a supply chain perspective to explore technological activities in the process of developing, assembling, installing and running a PV system for power generation. Upstream, midstream and downstream segments of the supply chain are

\footnotetext{
${ }^{1}$ [22] count patent families where patents have been granted in the US and in China.
} 
considered. ${ }^{2}$ However, the exact definition of the supply chain and the level of detail varies largely across the contributions. In general terms, the main limitation of these studies is the narrow definition of PV systems solely considering c-Si cells and modules. ${ }^{3}$

Existing results point out that in the industry emergence phase, China did not have competences in PV technologies. The recruitment of skilled Chinese entrepreneurs and the acquisition of foreign turnkey production lines were the main channels for technology adoption. The production process using manufacturing equipment did not require complex technologies and skills. At first this strategy of foreign technology acquisition did not bring domestic innovation capabilities [22]. However, learning process have been taking place. [12] describe a vertical integration process observed in Chinese leading PV manufacturing firms. Cell manufacturing companies entered the upstream segments to produce purified silicon, investing in research to develop their own technology. The vertical integration strategy ensured stable material supply and accelerated knowledge sharing across segments [12, p. 196].

The research results available do not give a clear view of the role of foreign actors for Chinese technological innovation. [22] point out that foreign direct investment (FDI) and joint-ventures have not played a significant role for technology development and innovation. According to case study analyses of technology transfer in low carbon sectors in China, foreign firms facilitate knowledge flows and learning for transferring existing technology for production processes. There is no evidence of knowledge transfer and technological collaboration in innovation activities [23]. Interestingly, in the study of patterns of technological collaboration in the solar cell industry using patents put forward by [24], China shows a stronger tendency to collaborate internationally than other countries (even though it has a small total number of patents in the field).

The reviewed studies suggest that the innovation capabilities to develop PV technologies in China have been accumulated through domestic research and development activities. The trade of intellectual property rights such as licensing has played no role. The role of FDI, collaborative research, and joint ventures has not been sufficiently discussed in the literature. Furthermore, there are is no deep quantitative analysis so far studying the process of accumulation of capabilities in PV in China at the industry level considering in detail the different technologies and industrial segments involved. The interactions of innovators as well as the roles of non-firm actors such as universities, research institutes, state-owned companies, and individuals in the innovation system are still uncovered in the literature. There is still open room for quantitative research to explore (i) whether China is transcending from producer to innovator in PV technology, (ii) the technological path followed in the catching-up process and (iii) the role of foreign actors in this process. Taking an evolutionary perspective the paper attempts to fill in these gaps in the literature.

\footnotetext{
2 Two core technologies are considered: "polysilicon technology" to prepare the key raw material for cell manufacturing (upstream segment), and "solar cell technology", which includes the production and assembly of PV cells into modules (midstream). Modules are then used in PV systems (downstream).

${ }^{3}$ A broader definition, including other technological families of PV cells as well as Balance of Systems (BoS) components for system integration is not considered in the literature.
} 


\section{CONCEPTUAL FRAMEWORK}

Our conceptual framework to study the accumulation of innovation capabilities for the development of PV in China and the technological networks shaping this process draws first on theoretical contributions to innovation in catching-up economies. Moreover, our research takes an innovation systems perspective to include networks and, at least to some extent, institutions in the process of accumulating innovation capabilities.

The role of innovation for economic development has been a matter of intensive research [25]. The literature on technological catching up stresses that the development and diffusion of technologies in latecomer economies go hand in hand with learning and knowledge accumulation [26, 27, 28, 29, 30]. Lall [27] and Kim [31, 30] conceptualize what they call 'technological capability' as a key factor driving economic development. At the national level, technological capability is a country's ability to use knowledge in order to understand, use and improve technologies. The concept of technological capability seems at first very fuzzy. Empirical research faces the challenge of explaining clearly what this concept stands for, especially if it attempts to capture it empirically.

Bell [32, p. 10] distinguish two types of technological capabilities triggering economic development in catching up economies: production capabilities and innovation capabilities. To him, "production capabilities" are technological capabilities embodied in physical and human capital needed to operate existing forms of technology. This capability requires good operational efficiency as well as skilled technical and blue-collar workforce. Considering the state of the art in research on the development of the PV industry in China described in the previous section, Chinese actors accumulated production capabilities to adopt and use the foreign technology becoming world leaders in PV cell manufacturing. "Innovation capability" on the other hand, enables the creation of new configurations of product and process technology as well as the introduction of modifications and improvements to technologies already in use [32, p. 10].

The accumulation of innovation capabilities is about moving from copying and adopting existing technology towards improving existing technologies or creating new ones.

The importance of networks for our research becomes clear if we consider the context in which capabilities are accumulated. According to Lall [27, 28], technological capability is accumulated through technological learning. He acknowledges that learning by catching-up economies can occur through access to international technology flows via FDI or through any other means of technology transfer mechanisms. However, he emphasizes that the assimilation and further development of technologies requires building new capabilities locally. This capability building occurs in collaboration. Usually firms interact with other organizations (suppliers, research institutes, training centres, universities and other supporting organizations) undertaking, supporting or complementing technological activities. Both, in-house accumulation of knowledge and linkages between organizations are hence essential to building the necessary capabilities for technological learning in developing countries [28, p. 100]. From this perspective, the accumulation of technological capabilities in PV in China takes place in a broad institutional context orchestrating the access to global technology flows in the PV sector 
and to national knowledge resources. The concept of technological system brings in this broader perspective, placing the accumulation of innovation capabilities in an institutional context [32, pp. 37-38].

Carlsson and Stankiewicz [4, p. 111] define a Technological System as "...a network of agents interacting in the economic/industrial area under a particular institutional infrastructure and involved in the generation, diffusion and utilization of a technology". Jacobsson and Johnson [33] identify three main building blocks in the Technological Systems of renewable energy technologies: (i) actors and their competences, (ii) the institutions shaping actors' technological decisions and (iii) the interactions between actors.

The main advantage of considering this systemic framework for our purposes of capturing innovation capabilities is the explicit consideration of interactions (networks) [32, pp. 3738]. The interest on networks in the field of innovation research and technology studies is not new and goes beyond the conceptualization of capabilities in the context of economic development [34]. Scholars point out that especially uncertainty and complexity inherent to the development of technologies foster interaction among organizations and network formation for the transfer of knowledge and information [35]. The contribution of networks to technological change draws also on the access they offer to the network members to additional resources (including information and knowledge). Moreover, in processes of technology adoption and development, networks influence the institutional setup shaping the spread of a technology as well as the definition of desirable characteristics of a technology [36]. Finally, in the context of catching-up, networks appear as the coordination mechanism enabling the access to external resources as well as the learning interactions for accumulating innovation capabilities [32].

The operationalization of these theoretical concepts should help us to answer our research questions. The empirical challenge lies first in developing indicators that capture the accumulation of innovation capabilities in China in PV. These are the capabilities triggering the move from producers to innovators in catching up economies. The accumulation of innovation capability is difficult to measure, but it can be assessed in terms of increasing levels of innovative capability [27]. We will derive appropriate patent indicators for this purpose (see section 4). Next, our empirical analysis will mainly focus on the network dimension of the PV technological system in China. To a certain extent, we will consider key technological attributes of the main actors involved in technological development as well as the key milestones of research and industrial policy in China. Nonetheless, actors and institutions are not the focus of this paper.

\section{DATA AND METHODS}

The empirical analysis introduced in this paper focuses on the inventive interactions side of technological systems, mainly technological knowledge networks of patenting activities. As an analytical framework, the technological systems framework stresses that the locus of innovation, and thus technological change, can be found within the interactions between types of actors and organizations.. From this perspective, the patent and network analysis developed in this paper differentiate the types of organisations 
involved in technological activities, their interactions [4] measured in terms of copatenting activities, as well as the role of transnational actors [37]. However, it is worth noting that from the perspective of technological systems, the interactions between actors include other relationships besides co-patenting activities. Our research is limited to technological activities involving patent applications and to those technological collaborations that can be traced through patent co-applications. These activities and interactions are at the far end of developing inventive outcomes susceptible of industrial application. The next sections discuss in detail the patent and network indicators used.

\subsection{Patent Analysis and Indicators}

Despite the well-known limitations for using patents as an indicator of technological innovation [38, 39], patent filings act as a key link between successful inventive activities and markets. Patent data covers large temporal and spatial scope, and it contains detail technical information about the inventions along with their legal and intellectual owners (or so called patent applicants and inventors respectively). Therefore, it provides a rich insight into the accumulated knowledge stocks, knowledge flows, as well as the cooperation activities in the sake of knowledge creation. Pavitt [39, p. 82] argued that since patent applications are filed over "the whole cycle of development and commercialisation of an innovation, it [can] be assumed that patent statistics reflect innovative - and not just inventive - activities". Furthermore, patent indicators (such as co-applications, co-inventions or citations) can be used to captured process of technology transfer and learning processes. Recent contributions have adopted these type of patent indicators to study technological collaboration and knowledge flows in China in the PV sector $[24,40]$.

In this paper, the study of innovation capabilities accumulated in the PV field in China is mainly grounded on the analysis of patent data. Drawing on [41] and using the EPO Worldwide Patent Statistical Database (PATSTAT) version 2015b, patent indicators are derived in terms of counts of transnational patents.

Transnational patent applications are defined as patent applications filed at the European Patent Office (EPO), and international patents filed under the Patent Cooperation Treaty (PCT), avoiding double counting of applications that belong to the same family, as described in equation 1.

$$
T N=\{x \mid x \in E P O \cup P C T\}
$$

(Equation 1)

Transnational patent applications are expected to have high economic and technological value, for which applicants seek protection in several markets cross the national borders. The indicators analysed in this paper hence capture accumulated PV innovation capabilities with a business potential from an international perspective. We refer to these as capabilities at the technological frontier ${ }^{4}$. Furthermore, to capture local innovation capabilities, patent applications are assigned geographically to the countries where

\footnotetext{
${ }^{4}$ Incremental innovations relevant for local markets only can be captured with domestic patent applications to national patent offices, or with the priority filings of patent families. Such activities are out of the scope of this paper.
} 
inventors are located (using the inventors' addresses). The focus of the empirical analysis is on the transnational patent applications that have at least one inventor located in China.

Nonetheless, the sole consideration of patent counts does not tell the full story. For this reason, we use forward citation index (Fwd_Citn) as a proxy for the quality of transnational patent applications. The index reflects the technological impact of inventive activities. It is calculated for each actor as the average number of citations received $\left(C_{i}\right)$ over patent life time ${ }^{5}$ (age) for all transnational patent applications $(N)$ filed by the actor (equation 2).

$$
F W d_{C i t n}=\frac{1}{N} \sum_{i=1}^{N} \frac{C_{i}}{\operatorname{age}_{i}}
$$

(Equation 2)

Furthermore, for a first assessment of the role of foreign actors in triggering the accumulation of innovation capabilities in PV technologies in China, we use two patent indicators put forward by Guellec \& de la Potterie, [42]. The indicators consider the geographical location of patent applicants (App) and inventors (Inv) to assess cross border interactions in technological activities. Accordingly, the first indicator we use is concerned with the offshoring activities of foreign firms in China. It is thus calculated as the ratio of patent applications assigned to Foreign Applicants and invented by Chinese Inventors $^{6}$ (FACI), to the total volume of Chinese Inventions (CI) based on fractional counting (equation 3).

$$
\text { FACI Rate }=\frac{\text { FACI }}{\mathrm{CI}} ; F A C I=\sum \frac{A p p_{F r g n} \cdot \operatorname{Inv} v_{C N}}{A p p \cdot I n v}, C I=\sum \frac{\operatorname{Inv} v_{C N}}{I n v} \quad \text { (Equation 3) }
$$

This indicator captures the extent to which actors outside China are seeking to protect inventions developed in laboratories or R\&D subsidiaries located in China. The larger the indicator, the stronger the role of foreign actors in driving the technological accumulation of innovation capabilities in China.

At the same time, we consider a second indicator for the Chinese activities sourcing knowledge from abroad. This indicator captures the extent to which actors (applicants) located in China are seeking for protection of technological inventions developed abroad (by inventors located outside China) (CAFI). The indicator is calculated as the ratio of CAFI to the total volume of patents owned by Chinese Applicants (CA) based on fractional counting ${ }^{7}$ (equation 4). Accordingly, it reflects the ability of Chinese actors to exploit technological inventions developed abroad.

\footnotetext{
${ }^{5}$ To make the forward citation index comparable across patent applications with different priority dates, the number of applications citing a patent under consideration $(\mathrm{x})$ is divided by the number of years elapsed since $\mathrm{x}$ has been filed.

${ }^{6}$ Considering a simple example of one patent application that has two applicants (one of them is Chinese and the other is foreigner) and three inventors (one is Chinese and the others are foreigners), FACI in this case equals $1 / 6$, while CI equals $1 / 3$, yields offshoring indicator of $1 / 2$.

${ }^{7}$ Considering the same example used in footnote 3 , CAFI in that case is equal to $2 / 6$, while CA equals $1 / 2$, which yields outsourcing indicator of $2 / 3$.
} 


$$
\text { CAFI Rate }=\frac{\mathrm{CAFI}}{\mathrm{CA}} ; C A F I=\sum \frac{A p p_{C N} \cdot \operatorname{Inv_{Frgn}}}{A p p \cdot I n v}, C A=\sum \frac{A p p_{C N}}{A p p} \quad \text { (Equation 4) }
$$

\subsection{PV Technical System}

To identify PV relevant inventions, we use the patent identification scheme developed by [43]. The classification goes beyond the narrow value chain definitions applied in previous studies. It offers a comprehensive and very detailed definition of different technologies and components along the production value chain of the PV large technical system, therefore, it is especially useful for analysing catching-up trajectories. Using a classification scheme mainly based on IPC classes, Shubbak [43] defines six PV fields: (i) solar cells, (ii) solar panels, (iii) electronics, (iv) monitoring and testing, (v) energy storage, and (vi) portable devices for lighting, heating and cooling purposes.

These main groups involve at the same time different technologies and subcategories. For instance, the first group, solar cells, represents an active research field in physics, photoand electro-chemistry, including high-tech developments in micro technology (and in recent applications nanotechnology). It comprises three generations of technology with five different technological families based on the semiconductor materials and manufacturing processes. These are: the matured first generation $1 \mathrm{G}$ technologies of crystalline silicon cells (c-Si); the second generation $2 \mathrm{G}$ technologies of thin-film technologies and single-junction Gallium Arsenide (GaAs) cells; as well as the third generation 3G technologies of multi-junction and emerging/organic PV cells [44, 45, 46]. These families differ widely in both manufacturing complexity and power conversion efficiency, and thus in the required development capabilities, costs, and practical applications.

For example, c-Si cells (with cell efficiency records $\eta \approx 21-27 \%$ ) and thin-film cells $(\eta \approx$ $14-23 \%$ ) are used for the civil applications such as residential and utility solar panels, or in some electronic devices such as calculators and lighting systems. The expensive high efficient technologies of GaAs $(\eta \approx 27-29 \%)$ and Multi-junction cells $(\eta \approx 31-46 \%)$ are widely used for space power applications [47, 45]. Organic technologies on the other hand $(\eta \approx 11-12 \%)$ are still under development phase in research laboratories. (Cell efficiencies source: [44])

The second PV group, solar panels, involves mainly mechanical engineering components and processes that are used for (1) solar modules manufacturing and protection, (2) panel encapsulation, (3) supporting structures for solar panels on building roofs, (4) optical and (5) thermal elements and arrangements associated with PV panels, and finally (6) $P V$ power plants.

The third group covers the electronic elements and electrical circuits that are directly associated with the PV power systems, such as modules' electrical connections, bypass diodes junction box, solar electric charge controllers and maximum power point trackers, as well as feeding circuit DC/AC inverters. Those components represent an active research field in electrical and power electronics engineering. 


\subsection{Social Network Analysis and Indicators}

The network analysis in this paper is based on co-applications of transnational patents with at least one inventor located in China. Each patent applicant is plotted as a network node whose size represents the number of patent applications made by the applicant in the period under consideration. An edge between nodes represents a co-application: two applicants are linked because they are applying together for a patent. Edges/coapplications are used as a proxy for technological collaboration in innovation processes. An edge captures hence interactions between two actors involved in the process of accumulating capabilities in PV technologies. These interactions may take place either because the technological invention occurred in collaboration or because the industrial exploitation of the technological invention involves both actors. The edges are weighted by the frequency of the co-applications in the period and is represented by the thickness.

The use of patent co-applications to capture these types of interaction has been extensively discussed in the patent indicators literature [48]. The main weakness of using co-applications as a proxy for collaborative activity lies on the fact that the proxy cannot capture all types of collaboration. For instance, actors involved in joint technology development may opt to form a joint venture for the collaborative R\&D project and apply for the corresponding patents with a single applicant. The indicator is hence underestimating collaborative activities [48, p. 62]. On the other hand, the use of coapplications allows to consider the different organizational forms of patent applicants in collaborative activities (Universities, research centres, private and state companies or individuals) if the affiliations are identified and classified accordingly ${ }^{8}$. Even though coapplications are not perfect measures of technology collaboration, the increasing number of joint-fillings involving national and international partners speaks for its value as a collaboration proxy [48].

Throughout the network analysis introduced in this paper, we calculate several indicators both at whole-network and single-node levels ${ }^{9}$. At node level, two embeddedness indicators are used:

The betweenness centrality (Btwn) of an actor reflects the importance of its position in connecting several components of the network, and thus, for our purposes, in transferring knowledge. The indicator is measured as the number of shortest paths between other nodes in the network that pass through the designated node $\left(\sigma_{s t}\left(n_{i}\right)\right)$, over the total number of such paths $\left(\sigma_{s t}\right)$ [49] (equation 5).

$$
\text { Btwn }=\sum_{s \neq n_{i} \neq t} \frac{\sigma_{s t}\left(n_{i}\right)}{\sigma_{s t}}
$$

The weighted degree (Deg) of an actor represents the total number of ties that directly link the actor with its patent co-applicants. If two actors have more than one joint patent,

\footnotetext{
${ }^{8}$ Co-inventions do not allow for this type of organizational analysis without a considerable effort in data gathering and actor and affiliation identification.

9 Social network analysis in this paper was conducted using Gephi 0.9.1 software [54]. For detailed explanation of network indicators, see [53].
} 
the additional collaborations are added to their degrees. Consequently, this indicator reflects the total number of collaborations for each actor.

The degree indicator is further aggregated at the network level by calculating the average degree of the whole network. It thus reflects the average number of technological collaborations per patent applicant during the time period under consideration.

Additionally, four indicators at the network level are considered for the sake of understanding the topology and overall characteristics of the co-patenting activities within the system:

Components represents disconnected subgraphs of the network, i.e. all nodes within a component are directly or indirectly connected, while no ties can be found between nodes that belong to different components. The number of components gives an indicator of the level of fragmentation of the network.

Network diameter is the longest of all calculated shortest paths $\left|\sigma_{s t}\right|$ in the network (equation 6). It reflects the linear size of the network and thus the largest distance between actors in the components.

$$
\operatorname{Dia}=\max \left(\left|\sigma_{s t}\right|\right)
$$

The graph density is the ratio between the actual number of edges $(E)$ in the network to the maximum number of possible edges based on the given number of nodes $(N)$ (equation 7). It reflects to which extent is the network close to a complete graph (where all nodes are directly connected). The higher the graph density, the stronger structure it has, and thus the easier knowledge could be transferred therein.

$$
\text { Density }=\frac{2 E}{N(N-1)}
$$

The Modularity $(Q)$ of the network is defined as the fraction of edges falling within clusters $\left(e_{i i}\right)$ minus the expected of such fraction in randomly distributed edges $\left(E_{r}\right)$ (equation 8) [50]. It is a measure of the strength of division of the network into clusters. Networks with high modularity have densely connected nodes within each cluster but sparse connections between different clusters [51].

$$
Q=\sum_{i} e_{i i}-E_{r}
$$

(Equation 8)

\section{RESULTS}

This section presents the empirical results of our patent and network analysis. It focuses on the accumulation of innovation capabilities within the Chinese PV sector, and on the position of the country in the global PV scene. Furthermore, it identifies the main actors driving the PV inventive activities at the technology frontier. First, the internal attributes of the main actors, represented by their specialization, quantity and quality of inventive activities are discussed. Second, the interactions between them, represented by copatenting networks, are examined. The network analysis considers the dynamic interactions between Chinese and foreign actors on the one hand, and between different 
types of organisations (firms, public sector research organisations, individuals, and the state) on the other.

\subsection{China's position on the global PV technological landscape}

Reviewing the worldwide transnational patent activities in PV technologies during the period 1977-2014, the trends in Figure 1 show that China occupies the sixth place in accumulated patent applications. It comes directly after Japan, the United States of America, Germany, South Korea, and France respectively. Chinese inventors were involved in about $3 \%$ of the total number of transnational patent applications in the PV field. Moreover, the trends show that China has even exceeded France in terms of annual transnational patent application counts during the past five years. Starting from a very low level of transnational patent applications in the PV field in the late nineties, patent activities by Chinese inventors started to increase dramatically in 2008, to reach the level of 110 transnational patent applications in a fractional counting basis in 2011, out of the total number of 2366 applications in the same year. The country experienced the highest growth rate in transnational patent applications in the field during last five years, with an average annual growth rate of 50\% during 2007-2011.

Figure 1: Patent trends of leading inventor countries in $\mathbf{P V}^{10}$

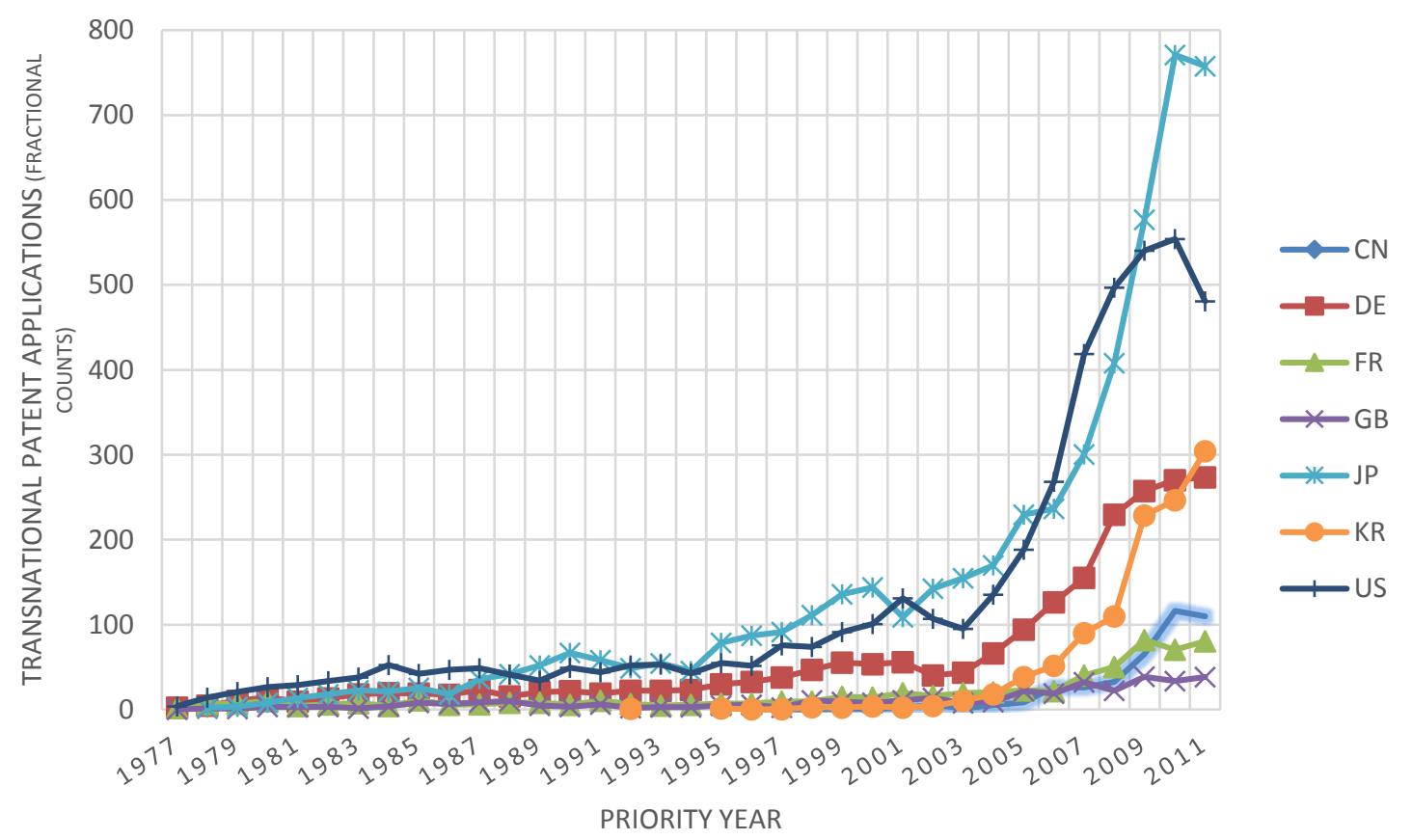

Source: PATSTAT 2015b. Author's own elaboration

\subsection{Chinese transnational patent applications in PV technologies}

From this section on, we consider the Chinese trend line of transnational patent applications shown in figure 1 for further analysis. We identified 1201 patent applications with at least one inventor located in China during the period 1988-2014. We will refer to

\footnotetext{
${ }^{10}$ According to the patenting administrative procedures, patent applications are made publically available eighteen months after the priority date, therefore to avoid data misinterpretation, the last years were not shown in the trends.
} 
these patent applications as Chinese PV transnational patents. The further investigation of these patents shows that the earliest patent was filed in 1988 by the Chinese Academy Physics Institute, to protect a general purpose manufacturing process of an alloy material that can be used in solar cell production. However, during the following eight years, no technological inventions in PV technologies were filed until 1996 when a continuously increasing number of foreigner and national applicants started to apply for PV patents. Table 1 shows the general statistics for applicants, inventors, and overall technological specialization within the Chinese patents portfolio.

Table 1: General statistics for Chinese PV transnational patents in 1988-2014

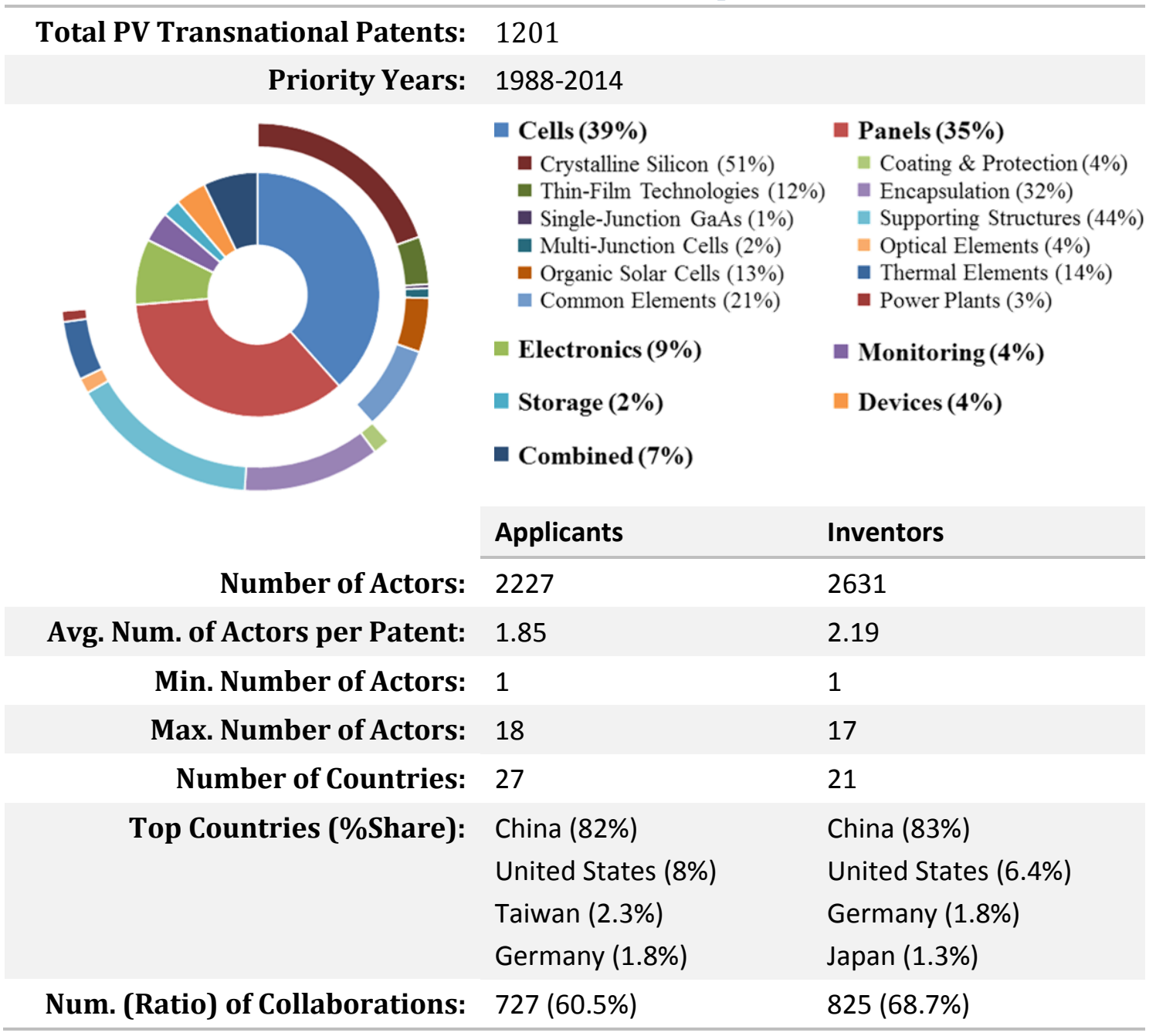

Data Source: PATSTAT 2015b. Author's own elaboration.

Looking at the technological specialization in the Chinese PV portfolio for the period 1988-2014, solar cell technologies and solar panels seem to be the dominant fields with the shares of $39 \%$ and $35 \%$ respectively. Although the PV electronics group has been experiencing a rapid growth in patenting activities since 2010, it is still lagging behind the first two groups with a share in the total patent fractional counts of about $9 \%$. On the other hand, monitoring and energy storage technologies have the lowest patent shares of $4 \%$ and $2 \%$ respectively. Inventions with combined nature make $7 \%$ of the total patents (table 1).

Furthermore, going one level deeper, the specialization analysis shows that the Chinese 
innovation capabilities mostly focus on the first generation $1 \mathrm{G}(\mathrm{c}-\mathrm{Si})$ technology with a share of $51 \%$ of all cell patent applications. A smaller share of patents $(12 \%)$ goes for the second generation $2 \mathrm{G}$ (thin-film) technologies. Interestingly, the organic cell types within third generation $3 \mathrm{G}$ technologies hold a share of $13 \%$.Nonetheless, China's capabilities in the high efficient types within $3 \mathrm{G}$ (GaAs and multi-junction cells) seem to be very small, with shares of only $1 \%$ and $2 \%$ respectively. In what concerns solar panel technologies, encapsulation and mechanical supporting structures hold the highest share in the Chinese portfolio with $32 \%$ and $44 \%$ of solar panel patents respectively.

Considering the internationalisation indicators of Chinese patenting activities in the PV sector, annual trends are presented in Figure 2. Regarding offshoring activities of foreigners in China, the share of transnational applications of Chinese PV inventions with applicants located abroad (FACI/CI) decreases remarkably after 2003 to a level below $10 \%$. On the other hand, for the Chinese technological activities sourcing knowledge from abroad, the share of transnational applications with Chinese applicants and foreign inventors (CAFI/CA) is moderate and quite stable throughout the period 2000-2013. The share remains below 10\% except in 2005 (18\%) and 2009 (14\%). These indicators speak for a moderate and relatively weak role of foreign actors in the recent developments of accumulation of innovation capabilities in China in PV technologies. 
Figure 2: Indicators for internationalisation of PV patenting activities in China

a) Foreign patent applicants and Chinese inventors

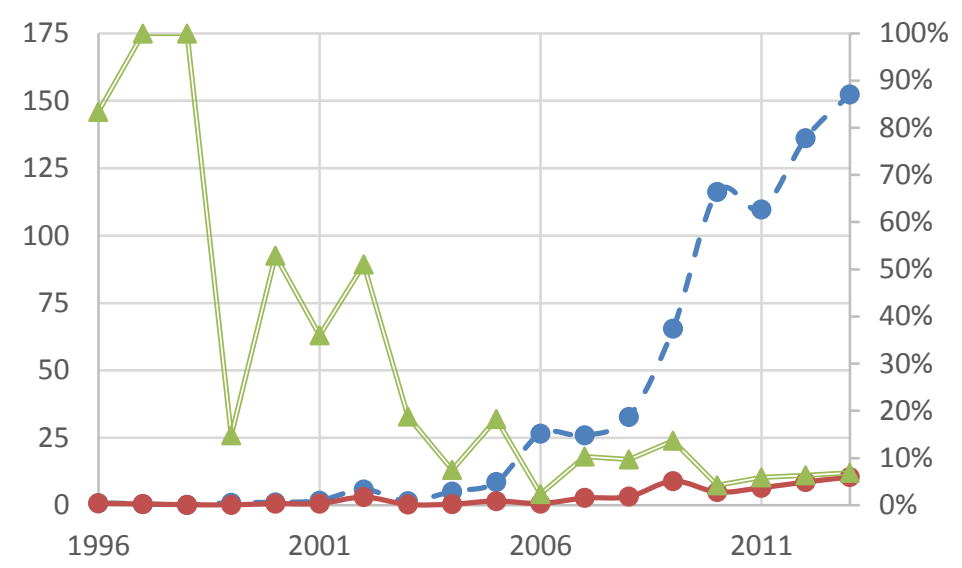

- - Transnational Patent Applications with Chinese Inventors $(\mathrm{Cl})$

$\longrightarrow$ Transnational Applications with Foreign Applicants and Chinese Inventors (FACl)

$\Longrightarrow \mathrm{FACl} / \mathrm{Cl} \%$

b) Chinese patent applicants and foreign inventors

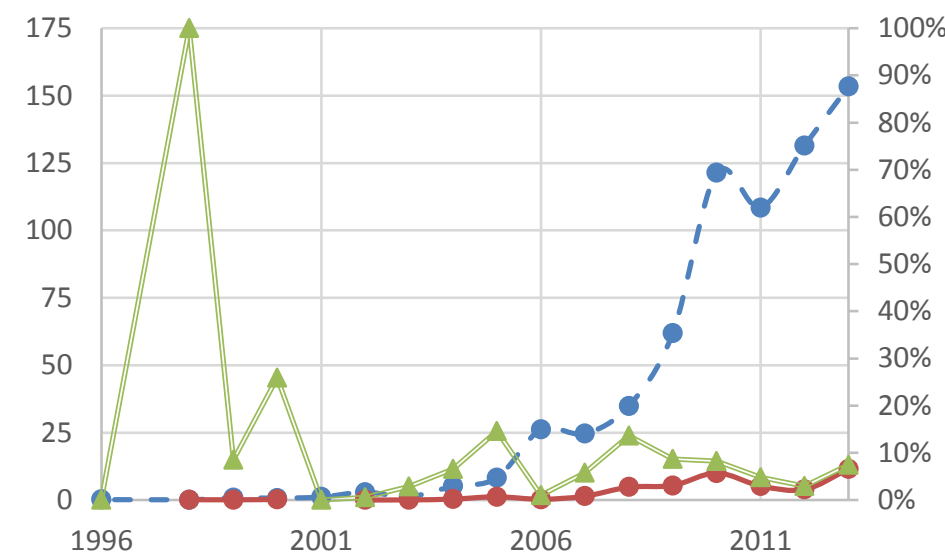

- - Transnational Patent Applicantios with Chinese Applicants (CA)

- Transnational Applications with Chinese Applicants and Foreign Inventors (CAFI)

$\longrightarrow \mathrm{CAFI} / \mathrm{CA} \%$

Data Source: PATSTAT 2015b, own elaboration.

Despite this low and decreasing role of foreign actors in terms of the quantity of patenting activities within the Chinese PV system, the analysis of patent quality shows a relatively advantage of their filings over applications assigned to local actors. The forward citation index for transnational patents applications of foreign applicants is at the level of 0.92 on average, comparing to 0.5 for patents of Chinese applicants, which means that the small share of patents assigned to foreign actors have nonetheless a higher technological impact.

\subsection{Co-patenting Networks and Institutions within the PV Technological System in China}

The network analysis introduced in this section focuses on how the population and the interactions of actors accumulating capabilities in PV technologies have evolved over time, and on the characteristics of the most important actors driving technological development within the institutional infrastructure. The analysis considers four periods: 1995-1999, 2000-2004, 2005-2009, and 2010-2014. The periods are consistent with the general institutional situation in China as represented by the five-year plans (FYP) adopted by the Central Committee of the Communist Party of China (the highest political body in the people republic). Each period in our analysis starts with the year of issuing 
the FYP as shown in figure 3. The figure additionally shows a timeline of the main government policies relevant to renewable energy and PV technology. Five types of policies are identified: rural electrification programs, regulatory policy instruments, science and research programs, supply push, and demand pull policies. Further detailed consideration of the instruments is presented later in the period-level analysis subsections.

Figure 3: Timeline of institutional milestones in the PV sector in China

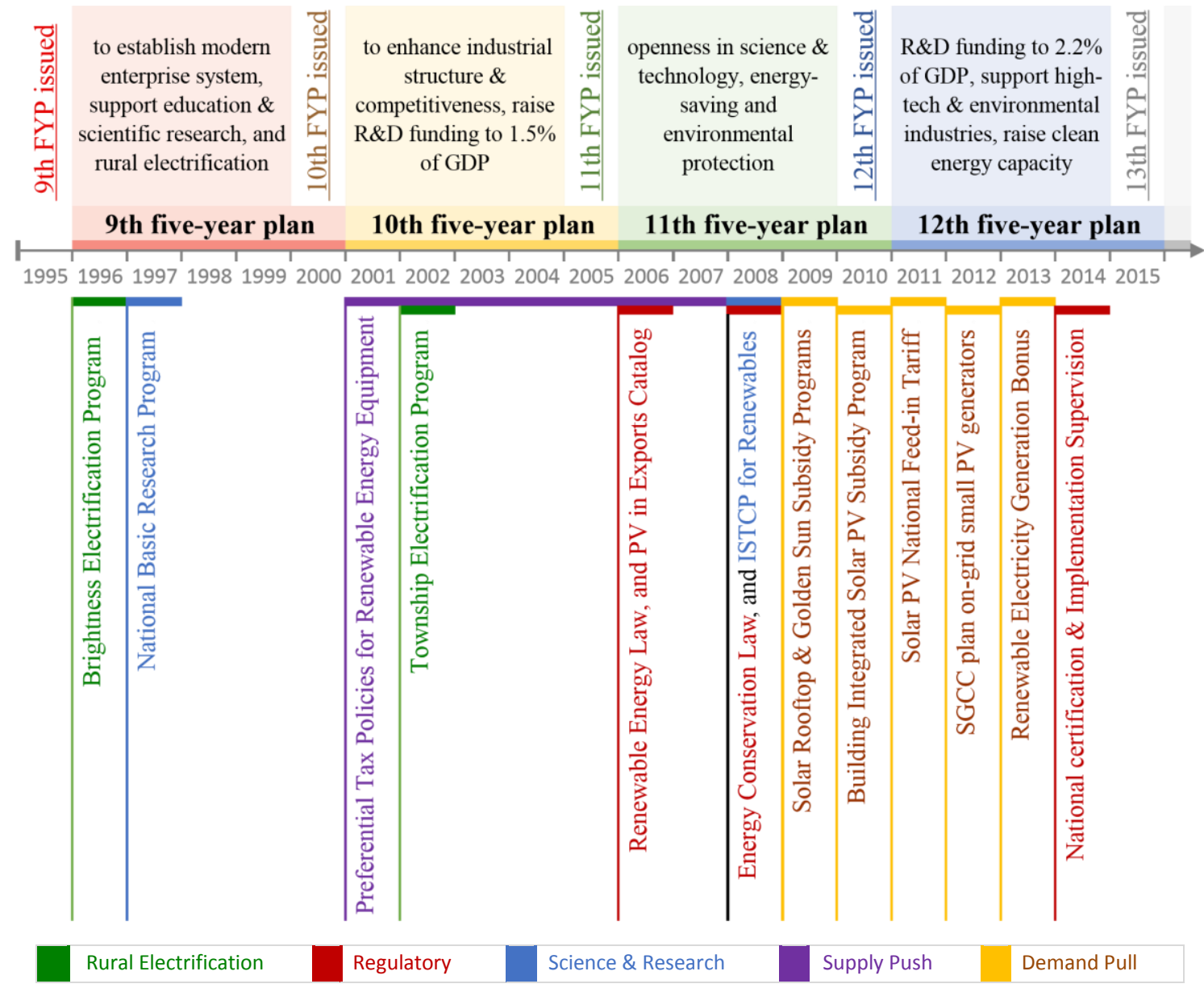

Data Source: compiled from Climate Policy Database by NewClimate Institute; China Internet Information Center (both accessed in October 2017); [20]; [11]. Author's own elaboration.

Considering the technological interactions, figure 4 shows the network in each period of analysis. The colour of the nodes represents the geographical location of the applicants. Between 1995 and 2014 the number of nodes has grown considerably, especially after 2004, with mainly Chinese applicants entering the population. Foreign applicants were located mainly in the United States (blue), Germany (green) and Taiwan (purple). Coapplications by actors located in different countries are relatively low and decreasing. The presence of foreign applicants has been decreasing continuously. 
Figure 4: Network dynamics of applicants and their respective geographical location. 4 periods: 1995-1999, 2000-2004, 2005-2009, and 2010-2014.

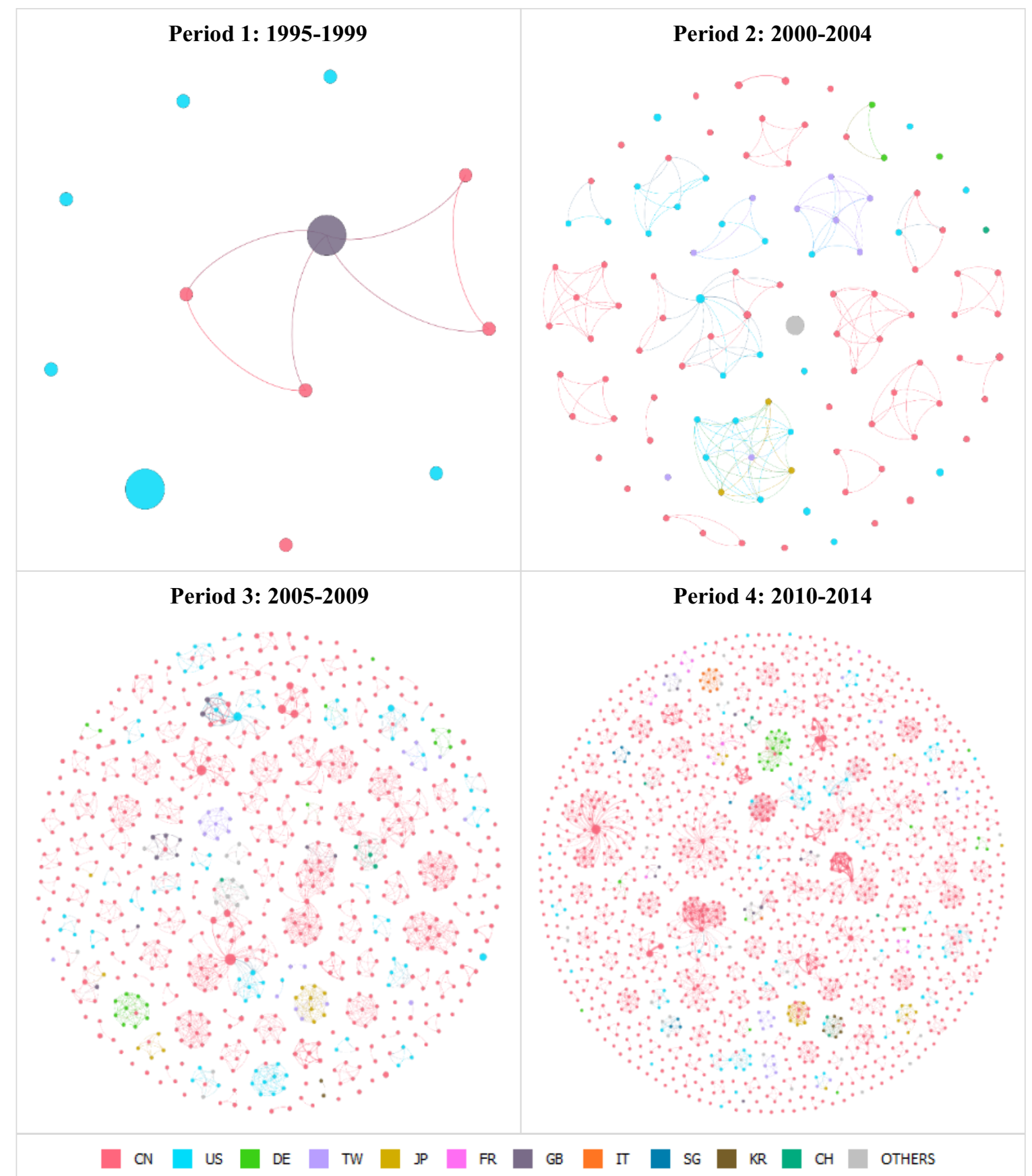

Nodes represent patent applicants; node size depends on the number of patents. Edge thickness represents the number of co-applications. Data extracted from PATSTAT 2015b. Author's own elaboration.

Table 2 presents a set of indicators related to patenting and co-application networks in the different periods. The number of transnational patent applications of Chinese inventions, the number of nodes (patent applicants) and the number edges (coapplications) have increased considerably between 1995 and 2014. The share of foreign applicants amounted more than 50\% in the period 1995-1999 and has dropped to $15 \%$ in the most recent period. The analysis identifies different types of actors as patent applicants: individuals, companies and public research organisations. Individuals hold the largest share $(76.9 \%$ in the full period $1995-2014)$ followed by companies with a share 
of $18.5 \%$.

In what concerns the technology fields within the PV system, we can observe clear changes in the relative importance of different fields in the total output of transnational patent applications. In the first period, patent applications concentrated on the field "devices" (low-tech) which amounted more than 50\% of the applications. However, in the most recent period this field holds only 3\% while solar cells and electronics (hightech) have reached considerable shares compare to the first period. Solar cells and panels amount for $70 \%$ of the patent applications between 2010 and 2014.

Table 2: Network statistics for the periods 1995-1999, 2000-2004, 2005-2009, 2010-2014.

\begin{tabular}{|c|c|c|c|c|c|c|}
\hline & & $\begin{array}{l}\text { Period I: } \\
\text { 1995-1999 }\end{array}$ & $\begin{array}{l}\text { Period II: } \\
\text { 2000-2004 }\end{array}$ & $\begin{array}{l}\text { Period III: } \\
\text { 2005-2009 }\end{array}$ & $\begin{array}{l}\text { Period IV: } \\
\text { 2010-2014 }\end{array}$ & $\begin{array}{l}\text { Full Period: } \\
\text { 1988-2014 }\end{array}$ \\
\hline \multirow{4}{*}{ 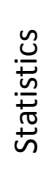 } & TN Patent Applications & 10 & 60 & 284 & 846 & 1201 \\
\hline & Nodes & 12 & 109 & 733 & 1488 & 2226 \\
\hline & Edges & 6 & 173 & 1844 & 3911 & 5789 \\
\hline & Foreign Applicants & $58.33 \%$ & $38.53 \%$ & $21.83 \%$ & $15.05 \%$ & $18.28 \%$ \\
\hline \multirow{5}{*}{ 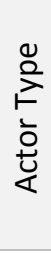 } & Individuals & $41.67 \%$ & $69.72 \%$ & $80.9 \%$ & $74.6 \%$ & $76.86 \%$ \\
\hline & Companies & $41.67 \%$ & $25.69 \%$ & $14.87 \%$ & $20.3 \%$ & $18.5 \%$ \\
\hline & Universities & $16.67 \%$ & $2.75 \%$ & $3 \%$ & $3.09 \%$ & $2.96 \%$ \\
\hline & Research Institutes & $0 \%$ & $0.92 \%$ & $0.68 \%$ & $1.48 \%$ & $1.12 \%$ \\
\hline & Government & $0 \%$ & $0.92 \%$ & $0.55 \%$ & $0.54 \%$ & $0.54 \%$ \\
\hline \multirow{6}{*}{ 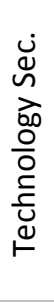 } & Solar Cells & $5.88 \%$ & $23.45 \%$ & $44.43 \%$ & $38.31 \%$ & $39 \%$ \\
\hline & Solar Panels & $23.53 \%$ & $23.45 \%$ & $31.11 \%$ & $33.19 \%$ & $35 \%$ \\
\hline & Electronics & $0 \%$ & $0 \%$ & $3.14 \%$ & $13.18 \%$ & $9 \%$ \\
\hline & Monitoring \& Testing & $17.65 \%$ & $17.24 \%$ & $3.52 \%$ & $3.93 \%$ & $4 \%$ \\
\hline & Energy Storage & $0 \%$ & $6.21 \%$ & $2.57 \%$ & $1.96 \%$ & $2 \%$ \\
\hline & Devices & $52.94 \%$ & $20 \%$ & $2.95 \%$ & $3.58 \%$ & $4 \%$ \\
\hline \multirow{5}{*}{ 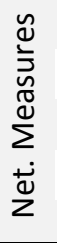 } & Average Degree & 1 & 3.174 & 5.031 & 5.257 & 5.201 \\
\hline & Network Diameter & 2 & 2 & 4 & 6 & 8 \\
\hline & Graph Density & 0.091 & 0.029 & 0.007 & 0.004 & 0.002 \\
\hline & Modularity & 0.111 & 0.898 & 0.963 & 0.966 & 0.974 \\
\hline & Components & 8 & 41 & 177 & 349 & 512 \\
\hline
\end{tabular}

Data extracted from PATSTAT 2015b. Author's own elaboration.

Regarding the network structure, Table 2 gives five network indicators capturing its characteristics and changes along the four periods. Even though the average degree has increased between the first and the fourth period, the network diameter, the density and the large modularity suggest that the population of patent applicants has grown to build a wide network of decreasing density clustered in isolated communities (components).

The main actors within the Chinese system are listed in (table 3 ) along with their activity periods $(p)$, their types, countries, quantity $(T N)$ and quality $(f w d)$ of transnational patents, specialization, and network embeddedness ( $\operatorname{deg}$ and $b t w n)$. 
Table 3: Main actors in the PV Technological System in China

\begin{tabular}{|c|c|c|c|c|c|c|c|c|}
\hline $\mathbf{P}$ & Actor* & Type & Ctry & $\mathbf{T N}$ & fwd & deg & btwn & Specialization \\
\hline 1 & Speedfam Corp. & $\mathrm{COM}$ & US & 2 & 0.86 & 0 & 0 & Monitoring, Testing \\
\hline 1 & Sol-Lite Manufacturing Co. & $\mathrm{COM}$ & $\mathrm{CN}$ & 1 & 0.13 & 2 & 0 & Panels, Devices \\
\hline 1 & Solar Wide Industrial Ltd & $\mathrm{COM}$ & $\mathrm{CN}$ & 1 & 0.00 & 2 & 0 & Devices \\
\hline 1 & Coleman Co. & $\mathrm{COM}$ & US & 1 & 0.36 & 0 & 0 & Devices \\
\hline 1 & California Institute of Tech. & EDU & US & 1 & 0.22 & 0 & 0 & Panels \\
\hline 1 & University Leland Stanford & EDU & US & 1 & 2.10 & 0 & 0 & Cells \\
\hline 2 & Omnivision Internat Holding & $\mathrm{COM}$ & KY & 11 & 0.30 & 0 & 0 & Panels \\
\hline 2 & Freescale Semiconductor Inc. & $\mathrm{COM}$ & US & 3 & 0.00 & 11 & 25 & Panels, Monitoring \\
\hline $2-4$ & Du Pont & $\mathrm{COM}$ & US & 19 & 1.80 & 37 & 186 & Cells, Panels \\
\hline 2 & Applied Materials Inc. & $\mathrm{COM}$ & US & 2 & 0.46 & 15 & 53 & Monitoring, Testing \\
\hline 2 & Infineon Technologies Corp & $\mathrm{COM}$ & US & 2 & 0.15 & 0 & 0 & Monitoring, Testing \\
\hline 3 & Silicon China HK & $\mathrm{COM}$ & $\mathrm{CN}$ & 8 & 0.21 & 13 & 3 & Cells, Panels \\
\hline 3-4 & Wuxi Suntech Power Co Ltd & $\mathrm{COM}$ & $\mathrm{CN}$ & 27 & 0.61 & 77 & 2181 & Cells, Panels \\
\hline 3-4 & BYD Co Ltd & $\mathrm{COM}$ & $\mathrm{CN}$ & 39 & 0.37 & 51 & 301 & Cells, Panels \\
\hline $3-4$ & Honeywell Int Inc & $\mathrm{COM}$ & US & 9 & 0.25 & 12 & 96 & Cells \\
\hline 3-4 & Gen Electric & $\mathrm{COM}$ & US & 14 & 0.92 & 20 & 369 & Electronics, Cells \\
\hline 3-4 & State Grid Corp China & GOV & $\mathrm{CN}$ & 16 & 1.00 & 56 & 1996 & Electronics \\
\hline 3-4 & Canadian Solar CSI Cells & $\mathrm{COM}$ & $\mathrm{CA}$ & 13 & 0.71 & 31 & 6 & Cells, Panels \\
\hline 3-4 & University Tsinghua & EDU & $\mathrm{CN}$ & 12 & 0.57 & 44 & 6717 & Cells, Panels, Testing \\
\hline 4 & AU Optronics Corp** & $\mathrm{COM}$ & $\mathrm{CN}$ & 49 & 0.63 & 92 & 1515 & Cells, Panels, Elect. \\
\hline 4 & Oceans King Lighting & $\mathrm{COM}$ & $\mathrm{CN}$ & 29 & 0.66 & 49 & 37 & Organic Cells \\
\hline 4 & Trina Solar Energy & $\mathrm{COM}$ & $\mathrm{CN}$ & 23 & 0.40 & 26 & 179 & Cells, Panels \\
\hline 4 & BOE Technology Group & $\mathrm{COM}$ & $\mathrm{CN}$ & 17 & 0.50 & 5 & 6 & Cells, Monitoring \\
\hline 4 & Xiamen Sanan Opto Tech. & $\mathrm{COM}$ & $\mathrm{CN}$ & 14 & 0.67 & 31 & 14 & Cells, Panels \\
\hline 4 & Shenzhen China Star Opt & $\mathrm{COM}$ & $\mathrm{CN}$ & 14 & 0.50 & 12 & 33 & Cells, Panels, Testing \\
\hline 4 & Inst. Microelectronics CAS & EDU & $\mathrm{CN}$ & 13 & 0.25 & 32 & 496 & Cells, Panels, Testing \\
\hline 4 & Yingli Energy Ltd & $\mathrm{COM}$ & $\mathrm{CN}$ & 11 & 1.00 & 33 & 580 & Cells, Panels \\
\hline 4 & Rongxin Power Electronics & $\mathrm{COM}$ & GB & 9 & 0.42 & 70 & 799 & Electronics \\
\hline
\end{tabular}

More detailed consideration of network structure, institutional infrastructure, and main actors in each period are given in the following subsections:

\section{The first period (1995-1999)}

This period started with the adoption of the $9^{\text {th }}$ FYP in 1995, which focused on the establishment of modern enterprise system, supporting of scientific research, and launching of national projects for rural electrification such as 'Brightness Electrification Program' in 1996. Accordingly, portable devices powered by off-grid renewable sources were of high interest. This was also reflected in the technological specialization within the Chinese PV technological system in this period, where the patent applicant population was relatively small (12 actors applying for 10 transnational patents) and patents were mainly within the portable devices field. Figure 5 gives the network with information on the geographical location of the actors (node colours) and the type of actors (label colours). 
Figure 5: Network of applicants in the first period (1995-1999)

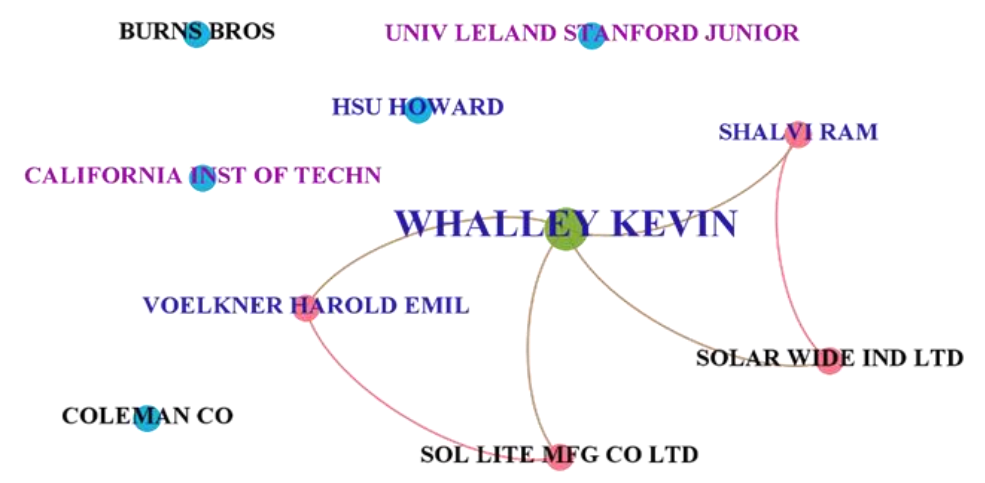

SPEEDFAM CORP

YAU ANDREW KAI CHING

\begin{tabular}{|c|l|}
\hline CN & COMPANY \\
US & UNTVERSITY \\
GB & INDIVIDUAL \\
\hline
\end{tabular}

Data extracted from PATSTAT 2015b. Author's own elaboration.

Foreign actors were located mainly in the USA. The main actor was an individual from Great Britain interacting with Chinese applicants. Interestingly, interaction among actors was very low. Actors from the USA were mainly universities that did not interact with Chinese applicants. The patent filed by Leland Stanford Junior University had the highest quality in terms of forward citation index $(f w d=2.1)$. The Chinese actors were two companies and two individuals interacting with the main actor in the period.

\section{The second period (2000-2004)}

In this period (figure 6), the network expands in terms of nodes and diameter. The main actors located in China or in the USA focused largely on the PV technology field of panels (which requires no high knowledge and innovation capabilities, however, is closer to the core of the PV technological system). In this period, public research organisations were no longer among the main actors. This coincided with an intensive policy focus on supporting the PV industry through preferential tax policies for renewable energy equipment during 2001-2007 (figure 3).

Interestingly, the main applicants located in China were individuals while the applicants located in the USA were only companies. This may be related to institutional aspects of patenting activities in each country. Already in this period, Chinese actors ranked among the top performers in terms of number of patent applications. The network was already quite divided in communities. Chinese actors interacted especially with other Chinese actors and, to a lesser extent, with companies located in the USA. The American company Du Pont appeared in the technological system in this period and stayed active through the next stages with patents of relatively high impact $(f w d=1.8)$ in cells and panels. 
Figure 6: Network of applicants in the second period (2000-2004)

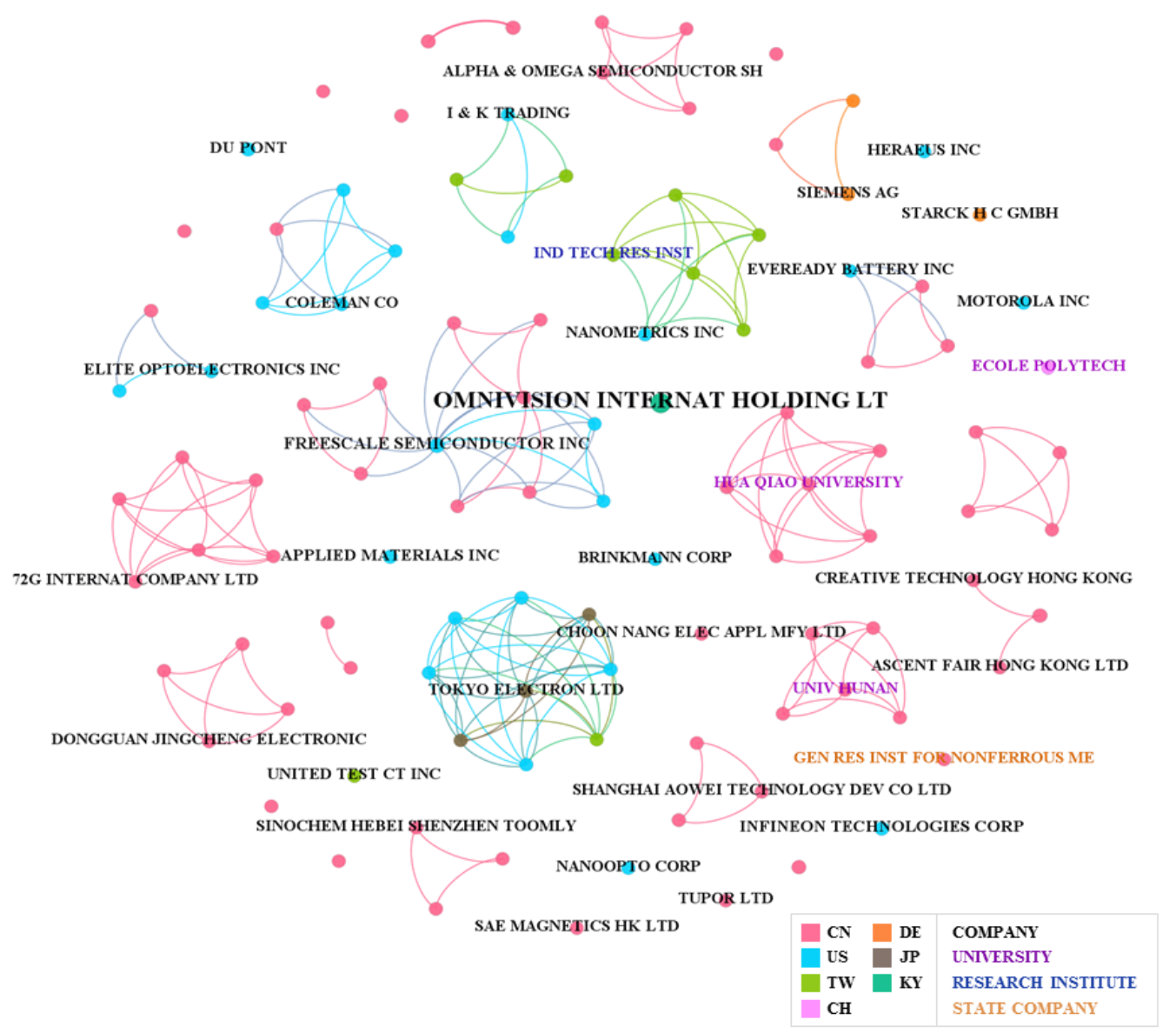

Data extracted from PATSTAT 2015b. Author's own elaboration.

\section{The third period (2005-2009)}

In this period, the network continues to expand in terms of nodes and communities established. Figure 7 shows the period network exclusively including nodes with at least two patents. This filter was applied for visualization purposes showing $16 \%$ of the total nodes in the period. Interestingly, the number of public research organisations (research institutes and universities) increased dramatically. The main actors in terms of patent applications were mostly located in China and focusing largely on cells and panels. The network reaches a higher degree of modularity with Chinese applicants co-applying largely with other Chinese applicants. This dramatic growth took place in the light of government policies being geared towards openness in science \& technology, supporting PV as export-oriented industry (was included in the 'Catalog of Chinese High-Tech Products for Export' in 2006) (figure 3).

Chinese companies took the lead among the top patent applicants. Wuxi Suntech ranked first in terms of number of patents as well as centrality measures. It was embedded in a cluster with American and Taiwanese co-applicants. The second and third ranked actors (BYD and Silicon China HK) were also located in China but not involved in cooperation with foreign applicants. The main foreign actors were companies located in the USA: Du Pont, Honeywell, and General Electric. Only Du Pont had relatively high degree and 
betweenness centrality suggesting intensive interactions with other actors located in USA, China, and UK. Interestingly, most of the main actors appearing in this period continue to file patents in the following period.

Figure 7: Network of applicants in the third period (2005-2009)

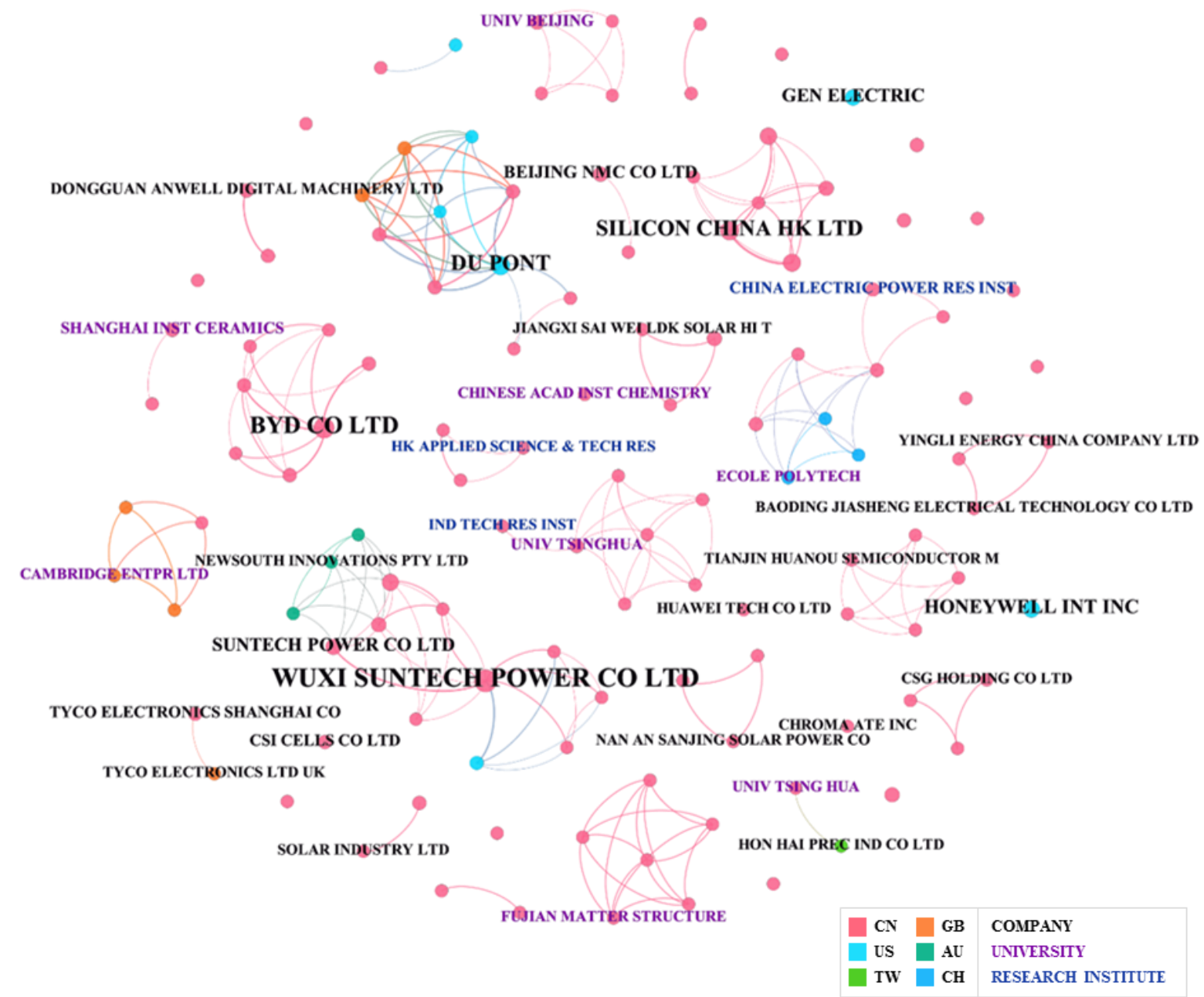

Nodes are co-applicants with at least 2 patent applications (17\% of total nodes in the period are visible).

Data extracted from PATSTAT 2015b. Author's own elaboration.

\section{The fourth period (2010-2014)}

Since 2009, an institutional shift in the governmental policy-mix towards demand pull can be noticed (figure 3 ). With the $13^{\text {th }}$ FYP stressing the goal of raising clean energy capacity nationwide, the number of applicants keeps increasing in this period and the network remains in a highly clustered structure (figure 8).

Considering network indicators, selected co-applicants seem interesting. The leader in terms of patent applications was the company embedded in a small cluster within the network. AU Optronics ranked highest in terms of patents and centrality measures. The company, nevertheless, was not interacting with any foreign actors. Next main actor showed a relatively isolated position in the network: BYD reached low levels of centrality. The companies Wuxi Suntech and State Grid Corp China (SGCC) had a different position in the network. These actors show very high degree and betweenness 
centrality in the considered period. They have hence prominent positions in the network in terms of number of interactions and with the role they play in connecting actors within the overall network. Interestingly, since 2014, Trina Solar Energy holds the global record of best research cell efficiency in poly c-Si cells [44]. Furthermore, a leading Chinese company focused in $3 \mathrm{G}$ organic cells appeared in this period, namely Oceans King Lighting.

Figure 8: Network of applicants in the fourth period (2010-2014)

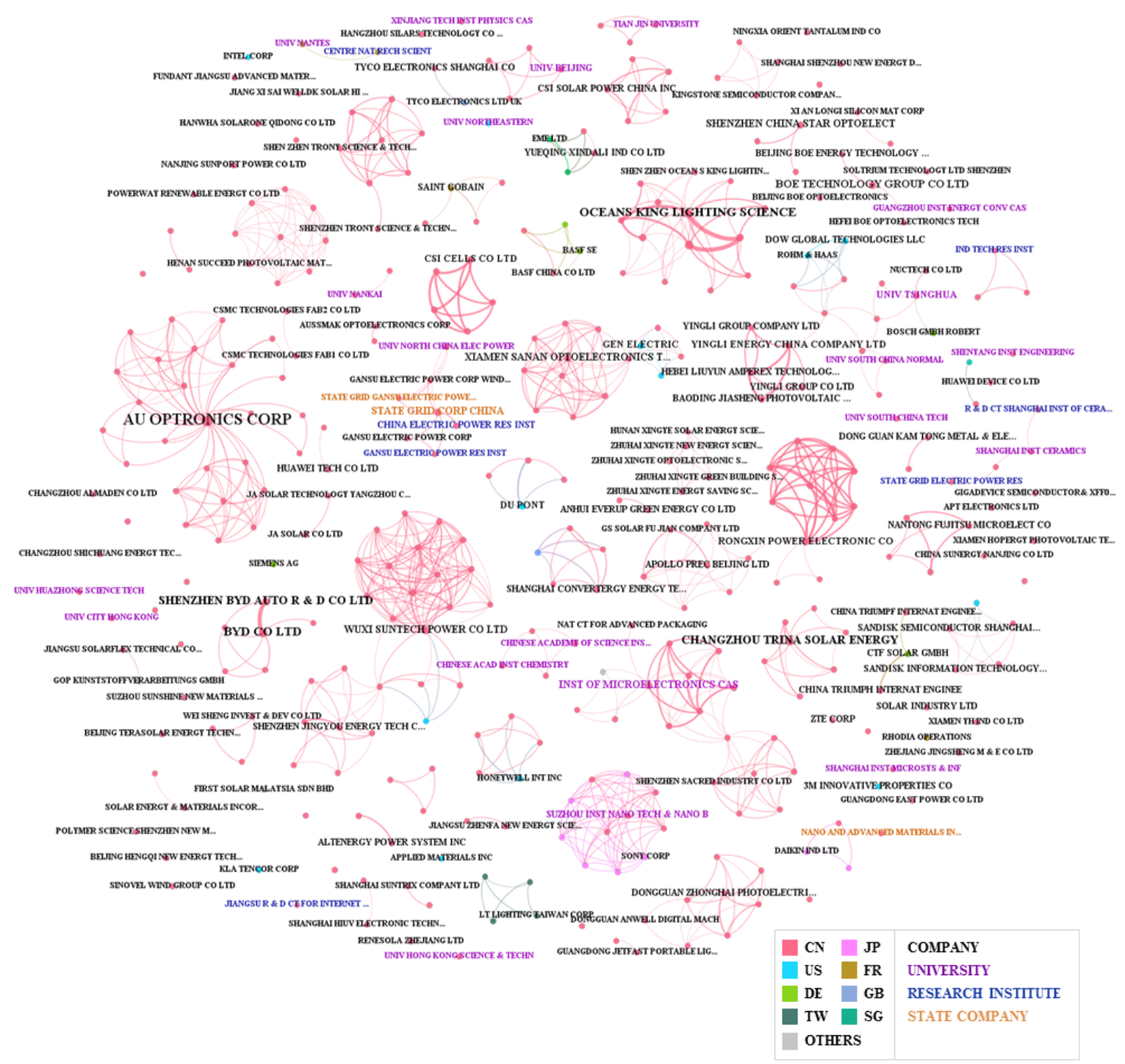

Nodes are co-applicants with at least 2 patent applications ( $26 \%$ of total nodes in the period are visible).

Data extracted from PATSTAT 2015b. Author's own elaboration.

Two universities appear among the top patent applicants in this period: Institute of Microelectronics at Chinese Academy of Sciences (CAS), and the University of Tsinghua, both held a relatively high number of patents (13 and 12 respectively) but most importantly they reached high levels of centrality comparing to other top ranked actors. These results speak for their importance in the network. 


\section{DISCUSSION AND CONCLUSION}

The results suggest a continuous process of accumulation of innovation capabilities in PV technologies in terms of transnational patent applications. Patent activities of inventions including at least one Chinese inventor started to increase dramatically after 2008. Since 2010, China is occupying the fifth place in terms of annual transnational patent filings in PV technologies, following Japan, USA, Germany and South Korea. Short-term policy instruments applied by the Chinese government in line with its successive five-year plans supported this development

In what concerns the role of foreign actors in this process: interestingly, foreign patent applicants of Chinese inventions were very relevant at the earliest stages of development. However, in the most recent period Chinese actors seem to have accumulated the innovative capabilities to trigger both inventing as well as patenting activities (which require a certain level of managerial skills), whereas the presence of foreign co-applicants diminishes drastically. The process of accumulation of innovation capabilities does not depend on foreign companies in the most recent period.

In general, the specialisation of Chinese innovation capabilities within PV system is mainly focused on c-Si cells and panel technologies, while the electronics field is gaining an increasing importance. The dynamic analysis shows an interesting catching-up trajectory. Chinese inventors established their innovation capabilities within the PV technological system in the late nineties by developing portable devices powered by solar cells. Acquiring the high-tech inputs (solar cells) from international markets, China protected inventions that implement these cells to power devices for daily life applications such as lighting, heating and cooling. The main institutional motivation was the rural electrification plans by the government.

The next step started in the first decade of the $21^{\text {st }}$ century by developing manufacturing capabilities in solar panels. Although most of the PV cells were still imported, increasing activities in fabricating solar cells were reflected in the growth of patent applications in the $1 \mathrm{G} \mathrm{c-Si}$ cell technologies. Chinese producers used to import solar grade silicon feedstock from large firms located in the USA, Japan and Europe [52]. Moreover, the Chinese manufacturers introduced and protected inventions in solar modules and panels that were mainly exported to international markets. During this stage, Chinese technological capabilities expanded towards activities with higher technological complexity. Nonetheless, China was still way behind the PV technological frontier of purified silicon feedstock for the $1 \mathrm{G}$ cells let alone the second and third generations.

Recently, more innovation capabilities have been accumulated in the field of $1 \mathrm{G}$ cells as exemplified by the growing share of patent applications in this field, in the increasing number of patents for silicon purification, as well as in the high cell efficiency records achieved by Chinese firms such as Trina Solar in 2014. Interestingly, the emerging 3G technology of organic solar cells holds a relatively high share in the recent patenting activities. The data thus suggest that the accumulation of innovation capabilities in China is occurring to a certain extent at the technological frontier of solar cell technologies. 
Considering the Chinese state policy incentives and green power plants establishment in the last decade $[52,11]$, an increasing demand for the associated electrical components has emerged. This demand drives development activities in the PV electronics field, which is mainly dominated by the SGCC and some large international firms. The accumulation of innovation capabilities is taking place in the development of feeding and inverting circuits as well as in power controllers.

The network analysis using patent data gives interesting insights in the interactions taking place over time. The population of actors involved in patenting activities in China has been continuously growing within a quite decentralised landscape of applicants, especially individuals. The network density has been decreasing with the increasing number of nodes. In general, the network displays a very high degree of modularity with Chinese patent applicants co-applying largely with other Chinese applicants. The patterns of interaction differ quite clearly across the main actors. For example, in the last two periods, Wuxi Suntech held a relative large number of patents within the matured $1 \mathrm{G}$ technologies of c-Si cells and was embedded in a dense cluster with foreign co-applicants. A slightly different pattern can be observed in AU Optronics, whose innovation capabilities were diversified along the full PV system value chain with a larger share of panels and c-Si cells. Nonetheless, the company was not interacting with any foreign actors. Other leading actors had low interactions but held important positions in terms of patent counts. For instance, BYD was embedded in a small isolated cluster but accounted for a considerable level of innovation capabilities in the most recent period. Following the same network pattern, the company Oceans King Lightening has accumulated capabilities in the emerging field of organic cells in the most recent period and was embedded in a relatively isolated cluster of Chinese actors.

In conclusion, the results suggest an increasing innovation capability building in China measured by transnational patent applications. Such patents are considered to capture capabilities at the technological frontier with high economic value. Although there is a gap between China and the leading economies at the frontier in PV technologies, the gap is decreasing. China is transcending from producer to innovator in PV technology. We tracked the Chinese technological trajectory and found an important role of institutional framework and learning activities in the process. The landscape of patents has been growing to create a decentralised network of interactions clustered in communities. Within these communities the level of innovation capabilities of the main actors and their patterns of interaction are quite heterogeneous. The role of foreign actors has decreased clearly. However, the results further suggest a gap between the strong position of China in the global market of PV modules and its modest share in transnational patent applications.

Throughout this research, several results were found that could raise questions to be investigated in further analysis. First, the gap between the Chinese market share and transnational patents suggest a puzzle that could be addressed through considering the industry dynamics and detailed catching-up processes over time. A second interesting insight into the Chinese PV system can be achieved by mapping patent data with production data through a worldwide comparative analysis. Furthermore, a third 
perspective could be to investigate the behind-frontier innovation capabilities in the field using priority filings, domestic patent applications, or patent families. Finally, the reasons behind the switch of Chinese policy orientation from supply push to demand pull in 2010 as shown in figure 3, can be deeper investigated in future research.

\section{REFERENCES}

[1] OECD, "Organization of Economic Cooperation and Development, Statistical Extractions MSTI Database,” 2016. [Online]. Available: http://stats.oecd.org/Index.aspx. [Accessed 13 December 2016].

[2] M. Godinho and V. Ferreira, "Analyzing the evidence of an IPR take-off in China and India," Research Policy, vol. 41, no. 3, pp. 499-511, 2012.

[3] F. Malerba, "Sectoral systems of innovation and production," Research Policy, vol. 31, no. 2, pp. 247-264, 2002.

[4] B. Carlsson and R. Stankiewicz, "On the Nature, Function and Composition of Technological Systems," Journal of Evolutionary Economics, vol. 1, no. 2, pp. 93-118, 1991.

[5] F. Malerba and R. Nelson, "Learning and catching up in different sectoral systems: evidence from six industries," Industrial and Corporate Change, vol. 20, no. 6, p. 1645-1675, 2011.

[6] UNEP, EPO and ICTSD, "Patents and Clean Energy: Bridging the Gap between Evidence and Policy, Final Report," United Nations Environment Programme, European Patent Office, and International Centre for Trade and Sustainable Development, Geneva, 2010.

[7] N. Marigo, "The Chinese Silicon Photovoltaic Industry and Market: A Critical Review of Trends and Outlook," Progress in Photovoltaics: Research and Applications, vol. 15, p. 143-162, 2007.

[8] X. Fu, "Key Determinants of Technological Capabilities for a Green Economy in Emerging Economies," in The United Nations Series on Development: Technology and Innovation for Sustainable Development , R. Vos and D. Alarcon, Eds., New York, Bloomsbury Academic, 2015.

[9] A. Jäger-Waldau, "PV Status Report 2013 (JRC Scientific and Policy Report EUR 26118 EN)," European Commission and DG Joint Research Centre, Ispra, 2013.

[10] R. Lema and A. Lema, "Technology transfer? The rise of China and India in green technology sectors," Innovation and Development, vol. 2, no. 1, pp. 23-44, 2012.

[11] M. Iizuka, "Diverse and uneven pathways towards transition to low carbon development: the case of solar PV technology in China," Innovation and Development, vol. 5, no. 2, pp. 241-261, 2015.

[12] F. Zhang and K. Gallagher, "Innovation and technology transfer through global value chains: Evidence from China's PV industry," Energy Policy, vol. 94, pp. 191-203, 2016.

[13] H. Zou, H. Du, J. Ren, B. K. Sovacool, Y. Zhang and G. Mao, "Market dynamics, innovation, and transition in China's solar photovoltaic (PV) industry: A critical review.," Renewable and Sustainable Energy Reviews, pp. 197-206, 2017.

[14] H. Sun, Q. Zhi, Y. Wang, Q. Yao and J. Su, "China's solar photovoltaic industry development. The status quo, problems and approaches.," Applied Energy, vol. 118 (Supplement C), p. 221-230, 2014. 
[15] P. Huang, S. O. Negro, M. P. Hekkert and K. Bi, "How China became a leader in solar PV. An innovation system analysis.," Renewable and Sustainable Energy Reviews, pp. 777-789, 2016.

[16] D. Song, H. Jiao and C. T. Fan, "Overview of the photovoltaic technology status and perspective in China," Renewable and Sustainable Energy Reviews, p. 848-856, 2015.

[17] M.-1. Huo and D.-w. Zhang, "Lessons from photovoltaic policies in China for future development.," Energy Policy, vol. 51, p. 38-45., 2012.

[18] Z. Zhao, S. Zhang, B. Hubbard and X. Yao, "The emergence of the solar photovoltaic power industry in China," Renewable and Sustainable Energy Reviews, vol. 21, pp. 229-236, 2013.

[19] W. Shen, "Who drives China's renewable energy policies? Understanding the role of industrial corporations," Environmental Development, p. 87-97, 2017.

[20] S. Zhang and Y. He, "Analysis on the development and policy of solar PV power in China," Renewable and Sustainable Energy Reviews, vol. 21, pp. 393-401, 2013.

[21] R. Quitzow, "Dynamics of a policy-driven market: The co-evolution of technological innovation systems for solar photovoltaics in China and Germany," Environmental Innovation and Societal Transitions, vol. 17, pp. 126-148, 2015.

[22] A. de la Tour, M. Glachant and Y. Ménière, "Innovation and international technology transfer The case of the Chinese photovoltaic industry," Energy Policy, vol. 39, p. 761-770, 2011.

[23] J. Watson, R. Byrne, D. Ockwell and M. Stua, "Lessons from China: building technological capabilities for low carbon technology transfer and development.," In: Climatic Change, vol. 131, p. 387-399., 2015.

[24] X.-P. Lei, Z.-Y. Zhao, X. Zhang, D.-Z. Chen, M.-H. Huang and J. e. a. Zheng, "Technological collaboration patterns in solar cell industry based on patent inventors and assignees analysis.," Scientometrics , vol. 2, p. 427-441, 2013.

[25] J. Fagerberg, M. Srholec and B. Verspagen, "The Role of Innovation in Development," Review of economics and institutions, vol. 1, no. 2, pp. 1-29, 2010.

[26] X. Fu, C. Pietrobelli and L. Soete, "The Role of Foreign Technology and Indigenous Innovation in the Emerging Economies: Technological Change and Catching-up," World Development, vol. 39, no. 7, pp. 1204-1212, 2011.

[27] S. Lall, "Technological capabilities and industrialization," World Development, vol. 20, no. 2, pp. 165-186, 1992.

[28] S. Lall, "Promoting technology development: The role of technology transfer and indigenous effort," Third World Quarterly, vol. 14, no. 1, pp. 95-108, 1993.

[29] D. Ernst and L. Kim, "Global production networks, knowledge diffusion, and local capability formation," Research Policy, vol. 31, no. 8-9, pp. 1417-1429, 2002.

[30] L. Kim, “ The Dynamics of Technological Learning in Industrialisation," International Social Science Journal, vol. 53, no. 168, pp. 297-308, 2001.

[31] L. Kim, "Building technological capability for industrialization: analytical frameworks and Korea's experience," Industrial and Corporate Change, vol. 8, no. 1, pp. 111-136, 1999.

[32] M. Bell, "Innovation Capabilities and Directions of Development," STEPS Working Paper 33, vol. Brighton:, no. STEPS Centre, 2009.

[33] S. Jacobsson and A. Johnson, "The diffusion of renewable energy technology: an analytical framework and key issues for research," Energy Policy, vol. 28, no. 9, pp. 625-640, 2000. 
[34] C. Freeman, "Networks of innovators: A synthesis of research issues," Research Policy, vol. 20, no. 5, pp. 499-514, 1991.

[35] W. Powell, K. Koput and L. Smith-Doerr, "Interorganizational collaboration and the locus of innovation: Networks of learning in Biotechnology," Administrative science quarterly, vol. 41, no. 1, pp. 116-145, 1996.

[36] S. Jacobsson and A. Bergek, "Transforming the energy sector: the evolution of technological systems in renewable energy technology," Industrial and Corporate Change, vol. 31, no. 5, pp. 815-849, 2004.

[37] J. Gosens, Y. Lu and L. Coenen, "The role of transnational dimensions in emerging economy 'Technological Innovation Systems' for clean-tech," Journal of Cleaner Production, vol. 86, pp. 378-388, 2015.

[38] D. Archibugi, "Patenting as an indicator of technological innovation: a review," Science and Public Policy, vol. 19, no. 6, pp. 357-368, 1992.

[39] K. Pavitt, "Patent Statistics as Indicators of Innovative Activities: Possibilities and Problems," Seientometrics, vol. 7, no. 1-2, pp. 77-99, 1985.

[40] C.-Y. Wu und J. A. Mathews, „Knowledge Flows in the Solar Photovoltaic Industry: Insights from Patenting by Taiwan, Korea, and China.," Research Policy, Bd. 41, pp. 524$540,2012$.

[41] R. Frietsch and U. Schmoch, "Transnational Patents and International Markets," Scientometrics, vol. 82, no. 1, p. 185-200, 2010.

[42] D. Guellec and B. V. P. De La Potterie, "The internationalisation of technology analysed with patent data," Research Policy, vol. 30, no. 8, pp. 1253-1266, 2001.

[43] M. H. Shubbak, "The Technological System of Photovoltaics; Identification and Analysis with Patent Classes," in The 29th Annual EAEPE Conference, European Association for Evolutionary Political Economy, Budapest, 2017.

[44] NREL, "National Renewable Energy Laboratory Photovoltaic Research: Best ResearchCell Efficiencies," 2016. [Online]. Available: http://www.nrel.gov/pv/. [Accessed 3 January 2017].

[45] S. Hegedus and A. Luque, "Achievements and Challenges of Solar Electricity from Photovoltaics," in Handbook of Photovoltaic Science and Engineering, S. Hegedus and A. Luque, Eds., Chichester, John Wiley \& Sons, 2010, pp. 1-38.

[46] K. Mertens, Photovoltaics : fundamentals, technology and practice, Chichester: John Wiley \& Sons, 2014.

[47] S. M. Hubbard, C. Bailey, S. Polly, C. Cress, J. Andersen, D. Forbes and R. Raffaelle, "Nanostructured photovoltaics for space power," Journal of Nanophotonics, vol. 3, no. 1, pp. 031880:1-031880:16, 2009.

[48] OECD, "Empirical Measures of Open Innovation," in Open Innovation in Global Networks, Paris, OECD Publishing, 2008, p. 49-75.

[49] L. Freeman, “"A set of measures of centrality based upon betweenness"," Sociometry, vol. 40, p. 35-41, 1977.

[50] M. Newman and M. Girvan, "Finding and evaluating community structure in networks," PHYSICAL REVIEW E, vol. 69, no. 026113, pp. 1-15, 2004.

[51] V. Blondel, J.-L. Guillaume, R. Lambiotte and E. Lefebvre, "Fast unfolding of communities in large networks," Journal of Statistical Mechanics: Theory and Experiment, vol. October, no. P10008, 2008. 
[52] D. Fischer, "Challenges of low carbon technology diffusion: insights from shifts in China's photovoltaic industry development," Innovation and Development, vol. 2, no. 1, pp. 131146, 2012.

[53] M. O. Jackson, Social and Economic Networks, New Jersey: Princeton University Press, 2008.

[54] M. Bastian, S. Heymann and M. Jacomy, "Gephi: an open source software for exploring and manipulating networks," California, 2009. 